\title{
МІРОСЛАВ ДРОЗДА. «ПОЧАТКИ ХУДОЖНЬОЇ НОВОЧЕСЬКОЇ ПРОЗИ» ФЕЛІКСА ВОДІЧКИ У СВІТЛІ ТЕОРІЇ ПРОЗИ
}

\section{Переклад із чеської та коментарі Галини Клічак}

Перекладено за виданям: Miroslav Drozda. Vodičkovy Počátky krásné prózy novočeské ve světle teorie prózy. Česká literatura, № 4, 1990, st. 289-294.

Мірослав Дрозда аналізує дану статтю опираючись на англійське видання Vodička's The Beginnings of Modern Czech Prose Počátky krásné prózy novočeské in the Light of the Theory of Fiction у збірнику: P. Steiner, M. Červenka and R.Vroon ed., The Structure of the Literary Process. Studies dedicated to the Memory of Felix Vodička, Amsterdam / Philadelphia, 1982. Тут і надалі цитування відбувається саме цієї праці.

Фелікс Водічка передовсім знаний як історик літератури. Його теоретичні статті присвячені історії літератури та розробці їі методології. У працях з історії літератури Водічка скрупульозно розробляє методологічно -структурний аналіз пластів літературної традиції, їхніх зв'язків у творі та взаємозалежність із попереднім розвитком літератури. За таким принципом у книзі «Початки художньої новочеської прози» (Прага, 1948) автор підійшов до питання генези чеської художньої прози, іï структури всередині жанрової системи новітньої чеської літератури як вищого структурного цілого. Оскільки Водічка досліджував саме визначення жанрової структури, то результати роботи мають загальне теоретичне значення.

Методологічно «Початки...» походять зі світогляду Празького лінгвістичного гуртка (який орієнтувався на російську формальну школу у літературознавстві), що його Ян Мукаржовський визначав так: «... 3 тези, що для мистецького тексту $\epsilon$ типовим домінантна позиція естетичної функції, яка спрямовує поетичні твори на виразність замість повідомлення, а з розуміння розвитку літератури як іманентного руху всередині самобутнього рядка, що приймає імпульси з інших рядків, відповідно застосовуючи їх до власної внутрішньої діалектики».

Чітке творче застосування цих спільних методологічних принципів дало можливість Водічці, окрім іншого, відтворити $\mathrm{i}$ ключове значення Юнгманнового перекладу новели Шатобріана «Атала» ${ }^{1}$ - розгадати причину вибору даного твору, а також внесені перекладачем певні зміни в тексті, що відрізнялися від оригіналу, та зробити розбір Юнгманових неологізмів. Водічка довів, що неологізми не були мотивованими саме через «неповноцінність сучасної чеської мови, яка б могла слугувати для перекладу зрілого твору світової літератури» (с. 68), як це раніше вважалося, тут, скоріше, йшлося «про свідомий потяг до поетизму, до слів, що виражають поняття у незвичний спосіб

\footnotetext{
${ }^{1}$ Йозеф Юнгманн (1773-1847) - видатний діяч чеського Національного Відродження, зробив неоціненний внесок у справу відновлення чеської мови після ії занепаду, зокрема в 1805 році опублікував майстерний переклад новели Шатобріана «Атала», чим на практиці довів, що чеською мовою цілком і повністю можна перекладати високохудожні літературні твори світового рівня. - Прим. перекладача.
} 
як розмовною, так і літературною мовами, 3 тією лише метою, щоб автономність і перевага поетичного висловлювання виступила повністю на передні позиції» (с. 68-69).

«Початки ...»є всебічним аналізом формування новітньої чеської прози під знаком домінантної ролі естетичної функції. Чеська проза на початку XIX століття передовсім доводила, що є художньою літературою, мистецтвом; вона наголошувала на своїй мистецькості, поетичності, навіть близькості до віршованої поезії. Таке прагнення, мотивоване необхідністю руху Національного Відродження створити цілісну і розгалужену структуру чеської культури, укріплювалось у його поетичному спрямуванні естетичної орієнтації на європейський преромантизм. Його вплив у Чехії набув поширення, оскільки був суголосним з іманентними потребами розвитку чеської літератури.

Водічка не вдовольнився ані поділом мистецтва на категорії поетичності, естетизованості - ознак, із яких починається така проза, ані описом проявів цих напрямів в одиничних пластах тексту.

У розділі, де розглянуті теоретичні трактування прози Юнгманном, читаємо: «Це природно, що йдеться про поетичну (художню) прозу як протилежність поетичній віршованій мові» (с. 39). Таке правило знаходить своє застосування в усій праці. І в описі періоду, коли проза стає подібною до поезії, точніше, коли вона своєю формою замінює, доповнює чи підтримує функцію «бути художньою літературою», Водічка не перестає відстежувати риси, завдяки яким вона є антиподом поезіі.

«Початки...» саме тому й аналізують новітню художню чеську прозу порівняно $з$ поезією, а також - чим така проза відрізняється від текстів позамистецьких; праця також показує перепони, що лежать на шляху до такої необхідної поетизації, і є поштовхом до подальшого розвитку та необхідності нового відокремлення прози від поезії; згодом це проявиться і у вимогах до природності (порівняйте с. 341), тобто в оманливому приєднанні до літератури позамистецької, від якої спочатку мала б проза емансипувати.

Із характерною точністю і м’якістю Водічка констатує, що зміщення акценту на природність, орієнтир «на декотрі традиції старої прози, що звертаються до читача з народу», не означає звичайне повторення надбань минулих поколінь: «Те, що в перших десятиліттях 19 століття мало характер посередництва в популяризації, стало тепер предметом мистецької культури і було переведено до слугування вищим мистецьким замислам» (с. 342).

Художня проза (насамперед) відділила поетичність від позамистецьких текстів, імітацію непоетичності від поезії.

Це означає, що відпоетизована «природність» була керованою, що вона не була простою копією «природності» позамистецької, але їі реконструкцією відносно до поетичності і на фоні поетичності.

Через понад два десятиліття цим питанням почне займатися Юрій Михайлович Лотман. Він наполегливо відділятиме художню прозу в межах опозицій «поезія-проза». Не ставить знак дорівнює між нею i розмовною 
мовою, не зараховує до неї навіть і «численні невіршовані жанри у фольклорі і в російській середньовічній літературі». «Використовувати у даному випадку ті ж самі терміни - це плодити дифузність понять у нашій науці»².

Невіршовані жанри фольклору і середньовічна література не творили, за Лотманом, із поезією контрастну двоєдину пару, і не сприймалися як єдине ціле. Вони з'явилися ще до виникнення поезії, а тому ніколи не усвідомлювалися разом із нею як різновид одного мистецтва, а лише як два різних мистецтва - пісенне й усне. Тому і в невіршованій фольклорній творчості, і в середньовічній літературі зустрічаємося з іншим ставленням до розмовної мови, ніж у художній прозі 19 століття. Вона подається як контраст до поезії, як щось «природне», «нескладне», «протимистецьке», «вигадане» тощо, натомість уже згадані фольклорні і середньовічні жанри прагнуть саме до мистецькості, до відмінності від «звичайної» мови.

Проза в сучасному розумінні цього поняття поєднує в собі уявлення про «високе» мистецтво і про не-поезію. Сприймаючись у парі з поезією, вона діє як «неконструйованість» проти «мистецтва», але ця іiі неконструйованість і простота як мистецьке явище є чимось другорядним, власне, є імітацією неконструйованості, імітацією, яка своїм фоном являє саме мистецтво та складність. Із цієї точки зору прозаїчна структура при всій зовнішній «простоті» $\epsilon$ складнішою, аніж поетична. «... естетичне сприйняття прози було можливим лише на фоні поетичної культури. Проза - явище пізніше, ніж поезія, - виникла в період хронологічно зрілішої естетичної свідомості. Саме тому, що проза $\epsilon$ порівняно 3 поезією естетично другорядною і приймається на базі поезії, письменник може сміливо наближати стиль прозаїчної мистецької оповіді до розмовної мови, не боячись, що читач втратить відчуття того, що має справу не 3 реальністю, а $з$ iї репродукцією. Всупереч уявній простоті і схожості до розмовної мови проза естетично складніша, аніж поезія, і iї простота $\epsilon$ секундарною. Розмовна мова дійсно прирівнюється до тексту, у той час як мистецька проза = текст + "мінусові риси" поетично конвенційної мови»"

Звуження терміна «художня проза» лише для літературних текстів сучасного періоду ми розглядаємо у протиставленні до віршованої поезії як до свого антиподу, що навряд чи буде загально визнано. Чи діє у цьому випадку визначення Ю. М. Лотмана про дифузність понять у літературній науці, наприклад, тоді, коли до художньої прози зараховуємо «Декамерон» або шахрайський роман? Чи у творах такого типу можна якось зробити градацію в рамках опозиції «поезія-проза», тобто як реакції на сучасну поезію (ту, що не співається, а декламується чи читається)?

Якщо ж таке граничне обмеження художньої прози заледве загально прийнятне, то введення прози у стан антиномії з поезією (що так характерно для сучасної літератури) і підкреслення напруження між ними як джерела

\footnotetext{
2 див. Лотман Ю.М. Анализ поетического текста. -Ленинград, 1972. - С. 25.

${ }^{3}$ Там само, С. 26.
} 
розвиткового руху літератури, як вищої структури - $є$ безсумнівно методично плідним.

У цьому світлі ще більше вирізняється конструктивність «Початків...» Водічки, написаних стількома роками раніше. Праця Водічки, між іншим, доводить, що й у новітній чеській прозі, скоріше 3 точи зору розвитку, були порушені питання «природності» чи «простоти», і що шлях до цієї мети був ускладненим, тобто сама природність була, власне, імітацією природності новою, складнішою.

Праці Лотмана про структуру мистецького тексту (головним чином це праці «Структура художественного текста» i «Анализ поэтического текста») опираються переважно на поезію. Проза тут згадується лише у загальних рисах, вона виокремлюється передовсім як «не поезія». Тому і тези про серйознішу складність прози порівняно 3 поезією опираються більше на т. зв. мінусові методи (минус-приемы), тобто на позатекстові елементи структури, але не на аналіз внутрішньої будови прозаїчного тексту. У «Початках...» Водічка щодо цього є більш виваженим: міжтекстові стосунки і внутрішню організацію тексту автор відслідковує з однаковою увагою.

Скрупульозність історика літератури, який використовує свій методологічний арсенал на підтвердження конкретних структурних зв'язків між явищами, що достеменно емпірично з'ясовані й описані, свідчить про те, що і в такому світлі $є$ можливість модифікувати занадто строге класифікування за принципами бінарних протилежностей.

У той час, як Лотман, наприклад, вважає, що естетичне сприйняття прози стало можливим лише на базі культури поетичної, i що проза $\epsilon$ явищем пізнішим, яке за хронологією виникло у період більш зрілої естетичної свідомості, праця Водічки з одного боку цю точку зору підтримує (див. 3'ясування про ускладнений шлях до природності), але й водночас приносить вагомий аргумент: «У випадку чеської літератури поезія (Пухмаєрової школи), на чиєму грунті і вибудовувалася художня проза, постала у своїй жанровій системі як щось бідне, як зворотній бік поетичної культури, а тому проза замість неї допомагала якимось чином ту поетичну культуру сформовувати до кінця». Чеська поетична література, продовжує Водічка, «наприкінці XVIII століття прийняла наголошений склад віршування, який у тогочасному розумінні і в тій ситуації гальмував формування вищого поетичного стилю. Антиподом до строгості i механічності вірша пухмаєрівського стилю $\epsilon$ прозаїчний "numerus", який подає мовний вираз вільніше і легше» (с. 318). Художня ж проза в першу чергу допомагає розширити сферу «поетична», в ній зазвичай домінують віршовані тексти, i тепер, коли за іï допомогою довершилася багатша поетична культура, проза могла почати від неї віддалятися у напрямку до «природності».

Водічка через призму історії трактує роль прози в жанровій системі літератури. Саме така конкретика і необхідна у студіях внутрішньої організації прозаїчного тексту. Аналіз науковця від одиничних пластів лексики до 
складніших, вищих, тематично цілісних сьогодні спонукає до теоретичних роздумів про типологію речення і прив'язану до неї звукову організацію тексту. Розбір речення Юнгманнового перекладу «Атали» власне відображає розвиток чеської періодизації, починаючи від гуманізму; схоже історичне минуле описує Водічка, згадуючи про речення в прозі Лінди ${ }^{4}$.

Те, на чому акцентує Водічка в описі речення (посилаючись і на статистичні підрахунки), збігається 3 намаганням опиратися на теорію прози, поки йдеться про іï внутрішню організацію, про сегмент, який перегукується 3 віршем як основною складовою поетичного тексту. Така спроба була плідною, шкода лише, що не продовжилася так само широко у вивченні давнішої чеської прози, преромантичну фазу якої досліджував Водічка.

Поетизуючий напрям преромантичної прози породив такі властивості речення, як «патетизація одиничних інтонаційних елементів 3 характерною каденцією», «очевидна тенденція до розмірного ритму» (див. с. 109, про речення перекладу Юнгманна «Атали»), «точний тип ритмічної прози», ритмічність якої «дана одним лише усвідомленням постійного чергування фрагментів речення, які вимальовуються 3 тематичного i синтаксичного закріплення речення», а «підсилювана інтонацією монотонність фрагментів, де завжди складаються умови до того, щоб ми звертали увагу на розподіл ударного наголосу як більш актуалізований принцип ритміки» ( див. с. 223, про речення в прозі Лінди).

Особливість речення поетичної прози полягає у властивостях, які їі i наближають до віршованих текстів. Водічка це показав направду всебічно. Але як класифікувати речення орієнтоване на імітацію природності або простоти, тобто, речення, яке ховається під псевдопозамистецькістю? Водічка торкається цього у завершальній п’ятій частині праці «Початки...», у розділі III «Криза преромантичної прози, шляхи i можливості подальшого розвитку», обгрунтовуючи це на прикладі творчості Й.-К. Тила. «Не йшлося про справу, яка легко вирішується. Література, якій саме вдалося вибороти собі шлях до створення вищої літератури 3 мистецькими прагненнями, не могла повністю повернутися до народності. Основою залишилося писемне речення експозиційного стилю, але поступово вона була позбавлена періодичної синтаксичної складності і пересічення думок, а окрім того, було ціле оживлення діалогів розмовними елементами» (с. 341).

Що ж все-таки доводило належність такого речення до художньої прози? Те, що вона була позбавлена періодичної синтаксичної складності і т. д.? Чи не доходить тут власне до невдячного ототожнення белетристичної прози з прозою позамистецькою?

\footnotetext{
4 Йозеф Лінда (1792-1834) разом із Вацлавом Ганкою створив «Кралеводворський» і «Зеленогорський» рукописи, підробки, що мали би свідчити про давність визрілої та сформованої чеської літератури, i претендували на роки створення у період між VIII та XI ст. Саме літературний, мовознавчий та хімічний аналіз текстів у 19 ст. дав право громадськості засумніватися у їхній старовинності та правдивості. - Прим. перекладача.
} 
Водічка виразно звернув увагу на те, що в програмі «Початків...» не було, «щоб ми детально стежили за методами праці Тила» (с. 342). «Початки...» тоді були біля порогу цієї проблематики. Чи могла вона все ж вирішитися через посередництво стилістично-синтаксичного опису? Чи міг цей вид опису відкрити специфічно словесну мистецьку організацію прозаїчного тексту?

«Початки...» підштовхують до цього питання, але самі на нього прямо не відповідають. Подальший розвиток літературної науки посприяв Водічці у розробці іншої проблематики.

Здається, що шлях до осягнення специфічного прозового мистецького тексту треба насамперед шукати не у порівнянні типів реченнєвих конструкцій, а в певному системному принципі тексту як одного цілого.

Йдеться про різновидну типологічну сторінку так званої точки зору тексту, тобто «стосунку системи до іï суб'єкта» ${ }^{5}$, характерної саме для прози. Ця проблема вирішена у працях М. М. Бахтіна, присвячених роману. Бахтін вважав роман «найвиразнішою реалізацією художньої прози», сприймав іiі як самостійний літературний вид, який контрастує з усіма іншими, наприклад, 3 епосом, лірикою і драмою. Центральною тезою Бахтіна про специфічність художньої прози (роману) $є$ думка про іiі універсальну «діалогічність», орієнтовану на «чужу мову», «багатомовність» (многоречие).

На противагу цьому «чиста драма тяжіє до однієї мови, яку драматичні персонажі лише індивідуалізують. Драматичний діалог визначений зіткненням індивідуума в межах одного світу і єдиної мови» ${ }^{7}$. Також поезія, за Бахтіним, «працює у своїй мові так, ніби без неї не існує жодних інших мов». «Поет піддається ідеї однієї і єдиної мови, монологічно закритої оповіді» ${ }^{8}$. I в епосі існує винятково один-єдиний горизонт, а тому слово епічного героя «не ідеологічно вичленоване..., зливається 3 авторським словом», причому «автор також не виокремлює свою ідеологію, вона випливає з ідеології зазвичай відомої, як єдино можлива» 9 .

Порівняно з цим роман закладений на цілком іншому понятті стосунків між суб'єктом тексту і самим текстом. Це розуміння наближає автора і читача до спільної з героєм часово-оцінювальної площини, творить із них сучасників, людей, які разом можуть спілкуватися, приятелювати, вступати у довірливі стосунки. Це дає можливість авторові «у всіх своїх масках і подобах вільно пересуватися у зображуваному світі, що в епосі було абсолютно неприпустимим і закритим». «... зображальне авторське слово опиняється в одній площині зі словом зображуваним i може 3 ним вступити до діалогу i гібридних комбінацій» ${ }^{10}$.

\footnotetext{
5 див. Лотман Ю. М. Структура художественного текста. - Москва, 1970. - С. 320.

6 див. Бахтин М.М. Вопросы литературы и эстетики. Москва, 1975. - С. 81.

7 Там само, С. 216-217.

${ }^{8}$ там само, С. $211,109$.

${ }^{9}$ Там само, С. 147.

${ }^{10}$ Там само, С. 269-270.
} 
Якщо монолітність драматичного, ліричного, епічного тексту забезпечує «одиничний і єдиний» горизонт, то прозаїчний текст формується на взаємній орієнтації суб'єкта тексту і решти мовленнєвих сфер. Тому художня проза не може до себе прийняти найрізноманітніші позамистецькі жанри.

Кожен такий жанр є в ній переоцінений у тому розумінні, що спрямований до суб'єкта тексту і разом із ним творить «образ світу», горизонт всередині рухомий, але при цьому цілісний. Художня проза тут, власне, створена для того, щоби безперестанку всотувати у себе немистецьку мову і діалогізацію, змінюючи їх на мистецтво. Суб'єкт тут втрачає суверенність одного єдиного горизонту, ніби віддаляється від цієї позиції в ім'я невичерпного різноманіття свого предмету, світу, але водночас у цьому світі й крутиться, завдяки йому виманюється з власної ізольованості й однозначності, виокремлюючись у свою структурну цінність.

Із такої структури не можна, звісно, навіть і речення брати як таке, але треба дослідити іiі з точки зору діалогічної потенції, тобто місця в поліфонії контекстів даної прози. Такі контексти творять не лише одиничні персонажі твору та їх автор, текст може бути заснований на складній грі між реальними й формальними учасниками мистецької комунікації (реальним i формальним оратором та оповідачем). Лише за таких ситуацій дослідження речення в прозаїчному творі й може забезпечити визначення його місця у структурі тексту.

У часи, коли Фелікс Водічка писав про початки художньої новочеської прози, такі студії ще не були методологічно організовані. Всі праці Бахтіна вже були написані, але в переважній більшості не були загальновідомими. Час їхнього визнання мав ще настати.

I ось тепер настав. Праця Бахтіна скеровує передовсім до типології роману. Чи поставимо поруч працю Фелікса Водічки? Не робімо цього лише з пошани, але передовсім тому, що поруч із класифікацією типів та жанрів про свої права наполегливо проголошує історія літератури, безпосереднє поле діяльності чеського структураліста. I на цьому полі «Початки...» залишаються закликом до інтелектульної подорожі, стимулом до наслідування. Нічого з того, що в його книзі є лише як філологічне з'ясування, не втратило своєї наукової цінності та актуальності і через три десятиліття. Навіть більше, є всі підстави логічно поєднати зауваги Водічки з новими філологічними досягненнями і одного разу таки дописати «Історію художньої новочеської прози», вступним розділом якої вже є грунтовна праця «Початки...». 